\section{Source Variation in Physical and Chemical Properties of Coconut Coir Dust}

\author{
Michael R. Evans ${ }^{1}$ and Sreenivas Konduru ${ }^{2}$ \\ Department of Horticulture, Iowa State University, Ames, IA 50011
}

\author{
Robert H. Stamps ${ }^{3}$ \\ Central Florida Research and Education Center, 2807 Binion Road, Apopka, \\ FL 32703
}

\section{Additional index words. substrates, media, Cocos nucifera}

\begin{abstract}
Physical properties differed significantly among five Philippine-produced coco-

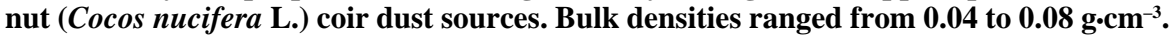
Air-filled pore space, water-filled pore space, and total pore space ranged from $9.5 \%$ to $12.6 \%, 73.0 \%$ to $80.0 \%$, and $85.5 \%$ to $89.5 \%(\mathrm{v} / \mathrm{v})$, respectively. Total solids accounted for $10.5 \%$ to $14.5 \%$ of total volume, and water-holding capacities ranged from $750 \%$ to $1100 \%$ of dry weight. Significant differences existed in particle size distribution, with the largest differences occurring for particle sizes $<8.0 \mathrm{~mm}$ and 0.25 to $0.50 \mathrm{~mm}$ in diameter. Chemical properties were determined for 12 sources from the Philippines, Sri Lanka, or Indonesia. The pH and electrical conductivities ranged from 5.6 to 6.9 and 0.3 to 2.9 $\mathbf{m S} \cdot \mathrm{cm}^{-1}$, respectively, and were significantly different among sources. No significant differences occurred among samples with respect to $\mathrm{Fe}, \mathrm{Mn}, \mathrm{Zn}, \mathrm{B}, \mathrm{Cu}, \mathrm{NH}_{4}-\mathrm{N}$, and $\mathrm{Mg}$ concentrations. Coir dust samples contained $\mathrm{Fe}, \mathrm{Mn}, \mathrm{Zn}, \mathrm{B}$, and $\mathrm{Cu}$ at 0.01 to 0.07 $\mathrm{mg} \cdot \mathrm{L}^{-1}$. The levels of $\mathrm{NH}_{4}-\mathrm{N}$ and $\mathrm{Mg}$ were 0.1 to 0.2 and 1.0 to $7.4 \mathrm{mg} \cdot \mathrm{L}^{-1}$, respectively. Significant differences occurred between sources for $\mathrm{Ca}, \mathrm{Na}$, and $\mathrm{NO}_{3}-\mathrm{N}$, with levels (mg. $\mathrm{L}^{-1}$ ) ranging from 1.0 to 24.3, from 22.3 to 88.3, and from 0.4 to 7.0, respectively. The widest ranges occurred in $\mathrm{K}\left(19\right.$ to $\left.948 \mathrm{mg} \cdot \mathrm{L}^{-1}\right)$ and $\mathrm{Cl}\left(26\right.$ to $\left.1636 \mathrm{mg} \cdot \mathrm{L}^{-1}\right)$. Sources differed with respect to cation exchange capacities, with values ranging from 38.9 to $60.0 \mathrm{meq} / 100 \mathrm{~g}$.
\end{abstract}

Artificial substrates are used extensively in the production of containerized greenhouse and nursery crops and are usually composed of several components. Among these, peat is one of the most widely used materials. Environmental concerns (Barkham, 1993; Buckland, 1993; Robertson, 1993) and increasing prices have generated significant interest in the development of alternatives to peat.

Most research into the development of peat substitutes has focused on the use of municipal or agricultural wastes. However, some of these materials are proving to be unsuitable because of their high degree of variability and their likelihood of containing undesirable materials such as glass, metal fragments, lead, and mer-

Received for publication 5 Feb. 1996. Accepted for publication 26 May 1996. Journal Paper no. J-16704 of the Iowa Agriculture and Home Economics Experiment Station, Ames; Project no. 3345; and supported by Hatch and State of Iowa Funds. Research conducted at Iowa State Univ., Ames. Use of trade names does not imply endorsement of the products named nor criticism of similar ones not named. This research was partially funded by the U.S. Agency for International Development through Chemonics International Consulting (Washington, D.C.) and the Agribusiness Systems Assistance Program (Manila, Philippines). The cost of publishing this paper was defrayed in part by the payment of page charges. Under postal regulations, this paper therefore must be hereby marked advertisement solely to indicate this fact.

${ }^{1}$ Assistant Professor.

${ }^{2}$ Graduate Research Assistant.

${ }^{3}$ Professor.

HortScience, Vol. 31(6), October 1996
Commercially produced CD was collected from the Philippines by the authors or provided by cooperators from Sri Lanka and Indonesia. For each of 12 locations (Table 1), five random samples were collected. All samples collected were referred to and marketed as CD. Chemical properties of all samples were determined, but only sources A, B, C, D, and $\mathrm{E}$ were used for physical properties testing due to limitations of sample volumes.

Particle size distribution was determined by rehydrating and air-drying $\mathrm{CD}$ samples. After samples were dried, particles sizes were separated by sieving 100-g samples on a CSC Scientific (Fairfax, Va.) rotary shaker for 10 min using screens with pore diameters of 8.0, $6.3,4.0,2.0,1.0,0.5$, and $0.25 \mathrm{~mm}$. Five samples were screened for each coir source. The weight of the material collected in each screen was determined. The weights and standard errors were plotted against pore size.

The air-filled pore space at container capacity [percent by volume $(\% \mathrm{v} / \mathrm{v})]$, waterfilled pore space at container capacity $(\% \mathrm{v} / \mathrm{v})$, total pore space $(\% \mathrm{v} / \mathrm{v})$, total solids $(\% \mathrm{v} / \mathrm{v})$, water-holding capacity at container capacity [percent by weight $(\% \mathrm{w} / \mathrm{w})$ ], and bulk density $\left(\mathrm{g} \cdot \mathrm{cm}^{-3}\right)$ were determined using loose-packed cores and methods adapted from Byrne and Carty (1989). However, we used 7.5 (height) $\times 7.5-\mathrm{cm}$ (inside diameter) cylinders with volumes of $345 \mathrm{~mL}$.

Substrate nutrient status was determined using the saturated media extract method as outlined by the North Central Regional Committee for Soil and Plant Analysis (Warncke, 1988). Electrical conductivity (EC) was determined using a Beckman (Cedar Grove, N.J.) solu-bridge (measured as $\mathrm{mS} \cdot \mathrm{cm}^{-1}$ ), and the $\mathrm{pH}$ was determined using an Orion (Cambridge, Mass.) $\mathrm{pH}$ meter. Nitrate $\mathrm{N}$ concentration was determined using the copperized cadmium reduction procedure (Keeney and Nelson, 1982) and ammonium was determined by the nitroprusside-salicylate procedure (Wall et al., 1975). The $\mathrm{Cl}$ concentration was estimated by the mercury thiocyanate procedure (Fixen et al., 1988). For P, K, Ca, Mg, B, Fe, $\mathrm{Mn}, \mathrm{Zn}, \mathrm{Cu}$, and $\mathrm{Na}$, we used the filtered

Table 1. Source of coir dust samples.

\begin{tabular}{|c|c|}
\hline $\begin{array}{l}\text { Source } \\
\text { code }\end{array}$ & $\begin{array}{l}\text { Sample source } \\
\text { or location }\end{array}$ \\
\hline $\bar{A}$ & Davao City, Mindano, Philippines \\
\hline B & $\begin{array}{l}\text { North of Davao City, Mindano, } \\
\text { Philippines }\end{array}$ \\
\hline $\mathrm{C}$ & San Pablo City, Luzon, Philippines \\
\hline $\mathrm{D}$ & Laguna province, Luzon, Philippines \\
\hline $\mathrm{E}$ & Laguna province, Luzon, Philippines \\
\hline $\mathrm{F}$ & Laguna province, Luzon, Philippines \\
\hline G & Commercial sample, Sri Lankay \\
\hline $\mathrm{H}$ & Commercial sample, Sri Lankay \\
\hline I & Commercial sample, Sri Lankay \\
\hline $\mathrm{J}$ & Raiugkas Bitung, Java, Indonesia \\
\hline $\mathrm{K}$ & Lampung, Sumatra, Indonesia \\
\hline & Tasik, Java, Indonesia \\
\hline
\end{tabular}

${ }^{2}$ Samples were collected from several coir dust factories in Laguna province.

${ }^{y}$ Samples were commercial products provided by various suppliers. 
Soll Management, Fertilization, \& Irrigation

extract for simultaneous inductively coupled argon plasma emission spectrometry (Jones, 1977; Munter and Grande, 1981). Cation exchange capacity (CEC) was determined using the ammonium saturation/displacement method (Brown and Warncke, 1988).

Five replications were tested for each source. An analysis of variance was conducted to determine if source significantly affected a physical or chemical property. Where significant differences existed, a LSD mean separation test $(\alpha=0.05)$ was conducted to establish significant differences between means.

\section{Results and Discussion}

All physical properties tested differed significantly among sources. Bulk density ranged from 0.04 to $0.08 \mathrm{~g} \cdot \mathrm{cm}^{-3}$ (Table 2). Air-filled pore space and water-filled pore space at container capacity ranged from $9.5 \%$ to $12.5 \%$ and $73.0 \%$ to $80.0 \%(\mathrm{v} / \mathrm{v})$, respectively. Total pore space ranged from $85.5 \%$ to $89.5 \%(\mathrm{v} / \mathrm{v})$, while solids accounted for $10.5 \%$ to $14.5 \%$ of total volume. Physical properties of CD generally were in ranges similar to what would be expected of sphagnum peat (Abad et al., 1989; Puustjarvi and Robertson, 1975 ). However, water-holding capacities of CD samples ranged from $750 \%$ to $1100 \%$ of dry weight. Depending on degree of decomposition, sphagnum peat generally holds $400 \%$ to $800 \%$ of its weight in water (Puustjarvi and Robertson, 1975). This result confirms unpublished anecdotal reports that $\mathrm{CD}$ has a higher waterholding capacity than sphagnum peat.

Most of the particles in the CD sources were from pith tissue (particles $<8 \mathrm{~mm}$ ) and were between 0.5 and $2.0 \mathrm{~mm}$ in diameter (Fig. 1). There were significant differences among sources with respect to the amount of very fine particles $(0.25$ to $0.50 \mathrm{~mm})$ and the amount of fiber ( $>8 \mathrm{~mm}$ ).

Source B had a higher average bulk density, water-filled pore space, total pore space, and water-holding capacity than any of the other samples. Source B also had the lowest air-filled pore space. Source D had the lowest average bulk density, water-filled pore space, total pore space, and water-holding capacity. Source D also had the highest air-filled pore space. Differences in physical properties might be accounted for because of the differences in particles sizes between the sources (Table 2). Source B contained little fiber $(<8 \mathrm{~mm})$, while it contained the highest percentage of its weight as particles with diameters in the range of 0.25 to $0.5 \mathrm{~mm}$. Source D contained significantly more fiber than the other samples. Increasing the particle size increases the number of noncapillary pores, increases air-filled pore space, and reduces water-holding capacity in peat (Puustjarvi and Robertson, 1975). Tilt et al. (1987) found that increasing the number of fine particles in a substrate increased the number of micropores and increased waterholding capacity of the substrate. It is therefore logical to assume that $\mathrm{CD}$ with high proportions of fiber and large particles will have larger air-filled pore spaces and reduced water-holding capacities as compared to CD

Table 2. Physical properties of coir dust from various sources.

\begin{tabular}{|c|c|c|c|c|c|c|}
\hline Source & $\begin{array}{l}\text { Bulk } \\
\text { density } \\
\left(\mathrm{g} \cdot \mathrm{cm}^{-3}\right)\end{array}$ & $\begin{array}{c}\text { Air-filled } \\
\text { pore space } \\
\text { at container } \\
\text { capacity } \\
{[\mathrm{v} / \mathrm{v}(\%)]}\end{array}$ & $\begin{array}{c}\text { Water- } \\
\text { filled pore } \\
\text { space at } \\
\text { container } \\
\text { capacity } \\
\text { [v/v }(\%)]\end{array}$ & $\begin{array}{l}\text { Total pore } \\
\text { space } \\
{[\mathrm{v} / \mathrm{v}(\%)]}\end{array}$ & $\begin{array}{c}\text { Total } \\
\text { solids } \\
{[\mathrm{v} / \mathrm{v}(\%)]}\end{array}$ & $\begin{array}{c}\text { Water-holding } \\
\text { capacity } \\
\text { [w/w (\%)] }\end{array}$ \\
\hline $\bar{A}$ & 0.05 & 11.5 & 74.9 & 86.4 & 13.6 & 910 \\
\hline B & 0.08 & 9.5 & 80.0 & 89.5 & 10.5 & 1100 \\
\hline $\mathrm{C}$ & 0.06 & 11.0 & 75.7 & 86.7 & 13.3 & 900 \\
\hline $\mathrm{D}$ & 0.04 & 12.5 & 73.0 & 85.5 & 14.5 & 750 \\
\hline $\mathrm{E}$ & 0.06 & 11.5 & 76.3 & 87.8 & 12.2 & 950 \\
\hline$P>\mathrm{F}$ & $* *$ & $*$ & $*$ & $*$ & $*$ & $*$ \\
\hline $\operatorname{LSD}(\alpha=0.05)$ & 0.02 & 2.0 & 6.4 & 3.5 & 3.0 & 125 \\
\hline
\end{tabular}

Ns, ****Nonsignificant or significant at $P<0.01$ or 0.001 , respectively.

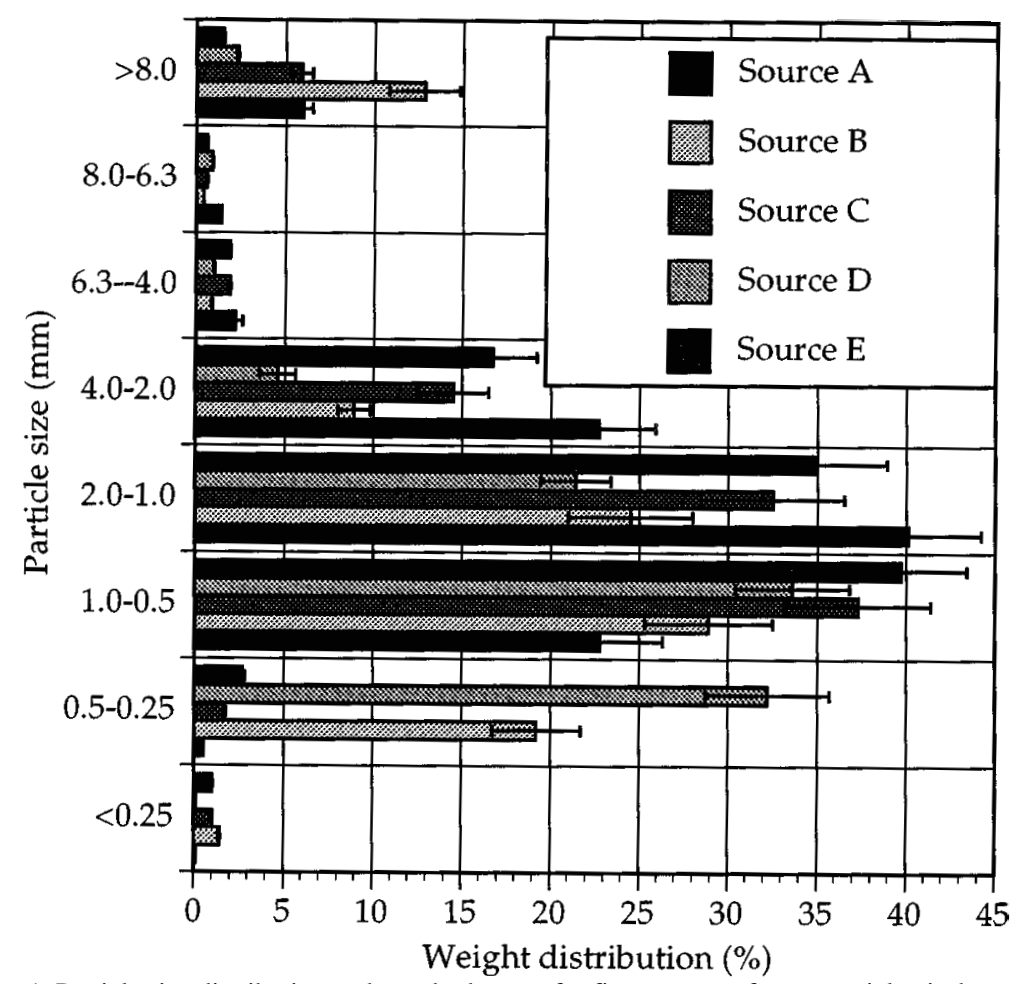

Fig. 1. Particle size distribution and standard errors for five sources of commercial coir dust.

with a larger proportion of small particles. Although coconut husks may vary in the proportion of pith and fiber tissue, the major factor that is likely to affect the relative proportions of particle sizes in processed CD will be factors associated with grinding the husk and screening the $\mathrm{CD}$. Varying either the degree of grinding, the screen size, or the screening time may impact the relative proportions of particle sizes in the product and thus the physical properties of the $\mathrm{CD}$.

The $\mathrm{pH}$ and electrical conductivities differed significantly among CD samples, with $\mathrm{pH}$ and electrical conductivities ranging from 5.6 to 6.9 and 0.3 to $2.9 \mathrm{mS} \cdot \mathrm{cm}^{-1}$, respectively (Table 3). All CD samples contained Fe, Mn, $\mathrm{Zn}, \mathrm{B}$, and $\mathrm{Cu}$ at 0.01 to $0.07 \mathrm{mg} \cdot \mathrm{L}^{-1}$ (detailed data not shown), with none of the differences being significant. The levels of $\mathrm{NH}_{4}-\mathrm{N}$ and $\mathrm{Mg}$ were 0.1 to 0.2 and 1.0 to $7.4 \mathrm{mg} \cdot \mathrm{L}^{-1}$, respectively, and were similar for all sources (Table 3). Calcium, $\mathrm{Na}, \mathrm{P}$, and $\mathrm{NO}_{3}-\mathrm{N}$ concentrations (in $\mathrm{mg} \cdot \mathrm{L}^{-1}$ ) differed significantly among sources, ranging from 1.0 to 24,22 to $88,1.3$ to 66 , and 0.4 to 7.0 , respectively (Table 3 ).
The ranges (in $\mathrm{mg} \cdot \mathrm{L}^{-1}$ ) were higher for $\mathrm{K}$ and $\mathrm{Cl}$, ranging from 19 to 948 and 26 to 1636 , respectively (Table 3 ).

In some coir factories, raw coconut husks are soaked in water before grinding. In some locations, this water may be saline and thus contribute to the high levels of $\mathrm{K}, \mathrm{Na}$, and $\mathrm{Cl}$ in the resulting CD. However, several of the samples in the study were from locations where husks were not soaked in water before grinding and contained high levels of $\mathrm{K}$ and $\mathrm{Cl}$, possibly because coconut plantation managers fertilize with $\mathrm{KCl}$ or $\mathrm{NaCl}$ (Menon and Pandalai, 1958; F. Soriano, personal communication). Coconuts are semi-halophytes and absorb salts and transport these to the developing fruit (Jeganathan, 1992). Since the $\mathrm{Cl}$ levels in the endosperm of coconut can be correlated with the level of $\mathrm{KCl}$ or $\mathrm{NaCl}$ applied to the tree (Remison et al., 1988), the Na, $\mathrm{K}$, and $\mathrm{Cl}$ levels in the mature husk may be affected by applying $\mathrm{KCl}$ and $\mathrm{NaCl}$ to the trees. Other chemical constituents also may vary based on fertilization practices. Therefore, the mineral elements in $\mathrm{CD}$ and the 


\begin{tabular}{|c|c|c|c|c|c|c|c|c|c|c|c|c|c|c|}
\hline \multirow[b]{2}{*}{ Variable } & \multicolumn{13}{|c|}{ Source } & \multirow[b]{2}{*}{ LSD } \\
\hline & A & $\mathrm{B}$ & $\mathrm{C}$ & $\mathrm{D}$ & $\mathrm{E}$ & $\mathrm{F}$ & $\mathrm{G}$ & $\mathrm{H}$ & $\mathrm{I}$ & $\mathrm{J}$ & $\mathrm{K}$ & $\mathrm{L}$ & $P>\mathrm{F}$ & \\
\hline$\overline{\mathrm{pH}}$ & 6.6 & 6.2 & 6.2 & 6.3 & 5.9 & 6.5 & 6.3 & 6.2 & 5.6 & 6.0 & 6.9 & 5.8 & $* * *$ & 0.2 \\
\hline $\mathrm{EC}^{\mathrm{y}}$ & 0.8 & 1.6 & 1.2 & 1.9 & 2.5 & 1.3 & 1.4 & 2.9 & 0.3 & 0.9 & 1.0 & 2.5 & $* * *$ & 0.5 \\
\hline $\mathrm{CEC}^{\mathrm{x}}$ & 39 & 48 & 45 & 55 & 60 & 46 & 43 & 50 & 49 & 45 & 50 & 57 & $* * *$ & 19.0 \\
\hline $\mathrm{NH}_{4}-\mathrm{N}^{\mathrm{w}}$ & 0.2 & 0.1 & 0.1 & 0.1 & 0.2 & 0.1 & 0.1 & 0.1 & 0.2 & 0.1 & 0.1 & 0.1 & NS & --- \\
\hline $\mathrm{NO}_{3}-\mathrm{N}^{\mathrm{w}}$ & 0.5 & 0.9 & 0.4 & 1.2 & 1.9 & 0.5 & 0.7 & 3.2 & 7.0 & 2.0 & 1.0 & 1.0 & $* *$ & 0.9 \\
\hline $\mathrm{P}^{\mathrm{w}}$ & 30 & 46 & 30 & 52 & 66 & 38 & 40 & 18 & 17 & 1.3 & 4.0 & 3.7 & $* * *$ & 10.4 \\
\hline $\mathrm{K}^{\mathrm{w}}$ & 236 & 596 & 434 & 698 & 810 & 351 & 388 & 948 & 19 & 221 & 209 & 327 & $* * *$ & 136 \\
\hline $\mathrm{Ca}^{\mathrm{w}}$ & 1.7 & 1.0 & 1.0 & 1.0 & 1.0 & 1.0 & 1.0 & 1.0 & 24 & 4.0 & 4.0 & 5.0 & $* * *$ & 0.4 \\
\hline $\mathrm{Mg}^{\mathrm{w}}$ & 1.5 & 2.8 & 2.3 & 1.6 & 2.5 & 1.0 & 7.4 & 4.4 & 1.0 & 2.0 & 4.0 & 6.7 & NS & --- \\
\hline $\mathrm{Cl}^{\mathrm{w}}$ & 183 & 435 & 300 & 560 & 721 & 377 & 337 & 843 & 26 & 517 & 512 & 1636 & $* * *$ & 167 \\
\hline $\mathrm{Na}^{\mathrm{w}}$ & 31 & 22 & 25 & 42 & 32 & 48 & 32 & 37 & 34 & 31 & 88 & 30 & $* *$ & 21.5 \\
\hline
\end{tabular}

${ }^{\mathrm{z}}$ See Table 1 for sources.

${ }^{\mathrm{y}}$ Electrical conductivity (EC) reported as $\mathrm{mS} \cdot \mathrm{cm}^{-3}$.

${ }^{\mathrm{x}}$ Cation exchange capacity (CEC) reported as meq/100 g.

${ }^{\text {w }}$ Reported as $\mathrm{mg} \cdot \mathrm{L}^{-1}$ in saturated medium extract.

ns, *******Nonsignificant or significant at $P<0.01$ or 0.001 , respectively.

degree of variability in those elements may be a function of not only how the material is processed, but of the conditions under which the raw material was produced.

CEC ranged from 39 to $60 \mathrm{meq} / 100 \mathrm{~g}$. This range is lower than that reported for sphagnum peat at 90 to $140 \mathrm{meq} / 100 \mathrm{~g}$ (Puustjarvi and Robertson, 1975) as well as the CEC reported on commercial labels (100 to $200 \mathrm{meq} / 100 \mathrm{~g}$ ). The discrepancy may be a result of $C D$ age. Large stocks of CD exist. The stocks are composed of CD that may be 20 years old or older (F. Soriano, personal communication) overlaid with recently added CD. Materials used in our study were from the surfaces of stock piles. Nelson (1991) and Puustjarvi and Robertson (1975) reported that the process of decomposition increases the CEC of organic materials. Therefore, the CEC of CD may depend on its age.

Although significant differences existed among sources with respect to chemical properties, most mineral elements were within ranges reported for sphagnum peats (Bunt, 1988) and considered acceptable for substrates to be used in most horticultural applications (Bunt, 1988; Peterson et al., 1989). The exceptions were $\mathrm{pH}, \mathrm{P}, \mathrm{K}, \mathrm{Na}$, and $\mathrm{Cl}$. The higher $\mathrm{pH}$ of $\mathrm{CD}$ would negate the need to incorporate lime to raise substrate $\mathrm{pH}-\mathrm{a}$ common practice when using peat in substrates - and the $\mathrm{P}$ and $\mathrm{K}$ found in $\mathrm{CD}$ may serve as a source of these mineral elements. However, $\mathrm{Na}$ and $\mathrm{Cl}$ levels may present problems when $\mathrm{CD}$ is used in substrates. Most sources indicate that $\mathrm{Na}$ and $\mathrm{Cl}$ levels of $75 \mathrm{mg} \cdot \mathrm{L}^{-1}$ or less are desirable in irrigation water (Bunt, 1988). Although only one sample had $\mathrm{Na}$ levels that exceeded this level, only one $\mathrm{CD}$ sample had $\mathrm{Cl}$ levels within the desirable range. It is unclear, however, whether $\mathrm{Na}$ and $\mathrm{Cl}$ in substrates are directly damaging to potted crops or whether the major effect is that of increasing the electrical conductivity of the substrate (Bunt, 1988).
Significant differences were observed among sources with respect to physical and chemical properties. Although the variability of most of these properties would not be of significant practical concern, others (i.e., $\mathrm{Na}$ and $\mathrm{Cl}$ ) could be problematic with respect to using CD in substrates. The variability observed may originate from variability that exists in the raw husk as well as from variation in processing. An understanding of how husk source, degree of grinding, screen size, degree of screening, and CD age affect physical and chemical properties is needed so that a consistent product with acceptable characteristics can be produced.

\section{Literature Cited}

Abad, M., V. Noguera, M.D. Martinez-Herrero, F. Fornes, and J. Martinez-Corts. 1989. Physical and chemical properties of sedge peat-based media and their relation to plant growth. Acta Hort. 238:45-56.

Barkham, J.P. 1993. For peat's sake: Conservation or exploitation? Biodiversity Conservation 2:556-566.

Brown, J.R. and D. Warncke. 1988. Recommended cation tests and measures of cation exchange capacity, p. 15-16. In: W.C. Dahnke (ed.). Recommended chemical soil test procedures for the north central region. North Dakota Agr. Expt. Sta. Bul. 499.

Buckland, P. 1993. Peatland archaeology: A conservation resource on the edge of extinction. Biodiversity Conservation 2:513-527.

Bunt, A.C. 1988. Media and mixes for containergrown plants. Unwin Hyman, London.

Byrne, P.J. and B. Carty. 1989. Developments in the measurement of air filled porosity of peat substrates. Acta Hort. 238:37-44.

Fixen, P.E., R.H. Gelderman, and J.L. Denning. 1988. Chloride tests, p. 26-28. In: W.C. Dahnke (ed.). Recommended chemical soil test procedures for the north central region. North Dakota Agr. Expt. Sta. Bul. 499.

Handrek, K.A. 1993. Properties of coir dust, and its use in the formulation of soilless potting media. Commun. Soil. Sci. Plant Anal. 23(3, 4):349-363.
Jeganathan, M. 1992. Nut water analysis as a diagnostic tool in coconut nutrition studies. Commun. Soil Sci. Plant Anal. 23(17-20):2667-2686.

Jones, J.B., Jr. 1977. Elemental analysis of soil extracts and plant tissue ash by plasma emission spectroscopy. Commun. Soil Sci. Plant Anal. 8:345-365.

Keeney, D.R. and D.W. Nelson. 1982. NitrogenInorganic forms, p. 643-698. In: A.L. Page (ed.). Methods of soil analysis, Part 2, 2nd ed. Amer. Soc. Agron., Madison, Wis.

Menon, K.P.V. and K.M. Pandalai. 1958. The coconut palm-A monograph. Indian Central Coconut Comm. Ernakulam, S. India.

Munter, R.C. and R.A. Grande. 1981. Plant tissue and soil extract analysis by ICP-atomic emission spectrometry, p. 653-672. In: R.M. Barnes (ed.). Developments in atomic plasma spectrochemical analysis. Heyden and Sons, London.

Nelson, P.V. 1991. Greenhouse operation and management. 4th ed. Prentice-Hall, Englewood Cliffs, N.J.

Peterson, J.C., L.L. Kramer, and J. O’Bryan. 1989. Just what is in my soil, anyway. Interior Landscape Industry 6(8):48-50.

Puustjarvi, V. and R.A. Robertson. 1975. Physical and chemical properties, p. 23-38. In: D.W. Robinson and J.G.D. Lamb (eds.). Peat in horticulture. Academic, New York.

Remison, S.U., G.O. Iremiren, and G.O. Thomas. 1988. Effect of salinity on nutrient content of the leafs of coconut seedlings. Plant \& Soil 109:135138.

Robertson, R.A. 1993. Peat, horticulture and environment. Biodiversity Conservation 2:541-547.

Tilt, K.M., T.E. Bilderback, and W.C. Fonteno. 1987. Particle size and container size effects growth of three ornamental species. J. Amer. Soc. Hort. Sci. 112:981-984.

Wall, L.L., C.W. Gehrke, T.E. Neuner, R.D. Cathey, and P.R. Rexroad. 1975. Total protein nitrogen: Evaluation and comparison of four different methods. J. Assn. Official Anal. Chem. 58:811817.

Warncke, D. 1988. Recommended test procedure for greenhouse growth media, p. 34-37. In: W.C. Dahnke (ed.). Recommended chemical soil test procedures for the north central region. North Dakota Agr. Expt. Sta. Bul. 499. 